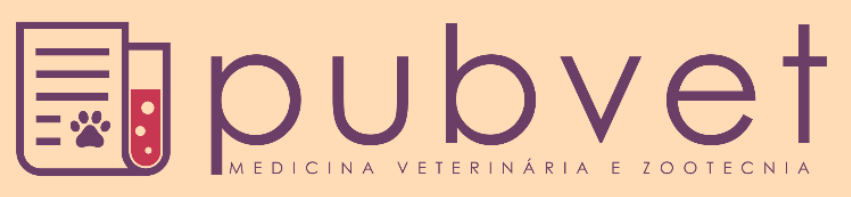

https://doi.org/10.31533/pubvet.v13n12a464.1-5

\title{
Prevalência de nematódeos intestinais em equinos da região sul do Rio Grande do Sul, Brasil
}

\author{
Natália Soares Martins ${ }^{1 *}$, Diego Moscarelli Pinto ${ }^{2} \bullet$, Thaís Cozza dos Santos ${ }^{3} \bullet$, Tatiana de \\ Ávila Antunes ${ }^{\circ}$, Tainá Ança Evaristo Mendes Cardoso $^{5}{ }^{\circ}$, Aníbal Janczak Torres ${ }^{6}{ }^{\circ}$, Pedro \\ Kutscher Ripoll ${ }^{3}{ }^{\circ}$, Leandro Quintana Nizoli $^{2}{ }^{\circ}$ \\ ${ }^{1}$ Doutoranda em Parasitologia, Universidade Federal de Pelotas, Departamento de Microbiologia e Parasitologia. Pelotas -RS Brasil. \\ ${ }^{2}$ Professor da Universidade Federal de Pelotas, Departamento de Veterinária Preventiva. Pelotas - RS Brasil. \\ ${ }^{3}$ Médico(a) Veterinário, Pelotas - RS Brasil. \\ ${ }^{4}$ Residente em Zoonoses Parasitárias, Universidade Federal de Pelotas, Departamento de Veterinária Preventiva. Pelotas - RS Brasil. \\ ${ }^{5}$ Acadêmica em Médica Veterinária, Universidade Federal de Pelotas. Pelotas - RS Brasil. \\ ${ }^{6}$ Doutor em Medicina Animal: Equinos. Pelotas - RS Brasil. \\ *Autor para correspondência, E-mail: nataliasmartins@outlook.com
}

\begin{abstract}
Resumo. O objetivo do estudo foi estimar a prevalência de nematódeos intestinais em equinos da região sul do Rio Grande do Sul, Brasil. Doze propriedades foram incluídas no estudo. Foram analisados 385 equinos, machos e fêmeas, com idade entre seis meses e 27 anos. As fazendas foram consideradas infectadas quando pelo menos um equino analisado foi positivo. A pesquisa parasitológica foi realizada por meio das técnicas de McMaster e Coprocultura. Ciatostomíneos foram encontrados em todas as propriedades e Strongylus vulgaris em apenas duas. A prevalência de nematódeos intestinais nos equinos foi: Ciatostomíneos $(96,36 \%)$, Parascaris equorum (12,21\%), Oxyuris equi $(10,13 \%)$ e Strongyloides westeri $(3,12 \%)$. O conhecimento acerca da prevalência dos nematódeos intestinais poderá contribuir para elaboração de programas de controle parasitário na região.
\end{abstract}

Palavras chave: cavalos, ciatostomíneos, parasitos

\section{Prevalence of intestinal nematodes in equines from the southern region of Rio Grande do Sul, Brazil}

\begin{abstract}
The objective of the study was to estimate the prevalence of intestinal nematodes in equines from the southern region of Rio Grande do Sul, Brazil. Twelve properties were included in the study. 385 equines, males and females, aged between six months and 27 years, were analyzed. The farms were considered infected when at least one equine had been reported positive. The parasitologic research was performed through McMaster and Coproculture techniques. Cyathostomins were found in all the properties and Strongylus vulgaris in only two. The prevalence of intestinal nematodes in the equines was: Cyathostomins (96.36\%), Parascaris equorum (12.21\%), Oxyuris equi $(10.13 \%)$ and Strongyloides westeri $(3.12 \%)$. The information concerning the prevalence of intestinal nematodes will contribute for the elaboration of parasite control programs in the region.
\end{abstract}

Keywords: horses, cyathostomins, parasites

\section{Prevalencia de nematodos intestinales en caballos del sur de Rio Grande do Sul, Brasil}

Resumen. Con el objetivo de evaluar la prevalencia de los nematodos intestinales en caballos del sur de Rio Grande do Sul, Brasil. Se estudiaron 385 equinos, machos y 
hembras, con edades entre seis meses y 27 años, provenientes de doce propiedades. Las propiedades se consideraron infectadas cuando al menos un caballo analizado fue positivo. La investigación parasitológica se realizó utilizando técnicas McMaster y Coprocultura. Se encontraron ciatostomas en todas las propiedades y Strongylus vulgaris en solo dos. La prevalencia de nematodos intestinales en los caballos fue: Ciatostomas (96.36\%), Parascaris equorum (12.21\%), Oxyuris equi (10.13\%) e Strongyloides westeri (3.12\%). El conocimiento sobre la prevalencia de nematodos intestinales puede contribuir a la elaboración de programas de control de parásitos en la región.

Palabras clave: caballos, ciatostomas, parásitos

\section{Introduction}

Intestinal nematodes cause severe limitations to the productivity and animal well-being of domestic herbivores, and the control of these parasites depends almost exclusively on the administration of anthelmintics. The parasitosis can cause a wide range of damaging effects to the equines health, in the most severe cases resulting in progressive weight loss, colic, diarrhea, anemia, bad hair condition, performance and growth reduction, and eventually death (Taylor et al., 2017).

Currently, the subfamily Cyathostominae is the parasitic group of greatest importance, consisting in more than 50 nematodes species that can parasite equines (Nielsen, 2012). These helminths are popularly known as cyathostomins or small strongyles and are the most prevalent and with higher parasitic intensity in equines in Brazil (Barbosa et al., 2001; Pereira \& Vianna, 2006) and in the world (Hinney et al., 2011; Kornás et al., 2010). The clinical signs associated to the infection by cyathostomins are variable, but are more commonly related to the growth reduction, weight loss, weakness, diarrhea and colic. It is highlighted the occurrence of granulomatous enteritis and larval cyathostominosis, potentially fatal illnesses, associated to the high development of immature stages in the large intestine wall (Peregrine et al., 2006; Pierezan et al., 2009).

Several other nematode species can infect equines; however, normally with lower prevalence than the cyathostomins (Hinney et al., 2011; Relf et al., 2013). Among these species, the most important in young equines, the ascarid Parascaris equorum, has great significance for being able to cause signs of respiratory and intestinal disease. According to Von Samson-Himmelstjerna (2012), P. equorum can result in quite severe clinical effects, as intestinal obstruction and/or perforation, that generally lead to death. Another significant nematode in young equines is the Strongyloides westeri. Though its low pathogenicity, it can cause severe enteritis in some conditions (Lucena et al., 2012). The Oxyuris equi afflicts equines of any age, and these equines can present massive infections, due to site contamination with parasite eggs, which have high survival rate in the environment. The oxyuriasis cause intense pruritus in the perianal region, which is the main sign associated to the infection (Reinemeyer \& Nielsen, 2013).

Historically, the Strongylus vulgaris was considered the most important parasite of the equine breeding, due to the migration of its young stages through the cranial mesenteric artery and its branches, providing arteritis and thrombus formation that interfere in the blood circulation; there also may be hypoxia, with predisposition to colic and intestinal obstruction (Taylor et al., 2017). Even though these parasites are highly pathogenic, they had lost its epidemiologic importance (Love et al., 1999) due to the frequent use of anthelmintics, widely used method in the last few decades that, unhappily, contributed for the development of the anthelmintic resistance specially for cyathostomins (Kaplan et al., 2004; Molento et al., 2008).

In the last years, the necessity of a new integrated approach in the control of these parasites became clear, as example the methods of selective or strategic treatment, besides other measures of management that reduce the infection of the hosts (Nielsen, 2012; Nielsen, 2015). The selective treatment is directed to those equines with high fecal egg count and has as objective to reduce the general use of anthelmintics, therefore reducing the selection pressure for the development of resistant parasites (Kaplan \& Nielsen, 2010). Regardless the used method, the knowledge concerning the prevalence of parasites in equines is fundamental, thus enabling the correct choice of drug to be used, contributing to the success of the antiparasitic program in the property. 
In order to support the development of future parasite control programs in the region, the present work had as objective to evaluate the occurrence of infection, by the main nematodes, in equines of the southern region of Rio Grande do Sul, Brazil.

\section{Material and methods}

This study was carried out in the period from August 2016 to October 2017, in twelve properties of the southern region of Rio Grande do Sul. 385 fecal samples of equines of the Criollo and crossbred breed, of both sexes, aged between three months and 27 years, were collected. The samples had been collected directly from the rectal blister, identified, conditioned in isothermal containers and transported to the Laboratório de Doenças Parasitárias of the Universidade Federal de Pelotas (UFPel), where they had been analyzed by two coprological techniques. Firstly, the eggs per gram of feces (EPG) counting had been obtained by the modified technique of McMaster (Gordon \& Whitlock, 1939), allowing the differentiation between strongylids, Parascaris, Oxyuris and Strongyloides eggs. Secondly, the coproculture had been performed in pool samples of each property, and the identification of the small strongyles (Cyathostominae) or large strongyles (Strongylinae) larvae was carried out. This work was approved by the UFPel Ethics Committee in Animal Experimentation under the registration number 7888.

\section{Results}

In the twelve analyzed properties, the equines were raised under extensive management and dewormed in every two, three or six months with different active ingredients. No significant changes of color, odor or consistency were identified in the samples analyzed. However, in samples collected from two properties, larvae of bright red coloration were visualized in the fecal bulk, with morphologic characteristics compatibles with nematodes of the subfamily Cyathostominae. In addition, injuries in the base of the tail of the equines had been observed in another property, associated to the presence of Oxyuris equi.

Equines infected by cyathostomins were found in all the properties, and in only two of them the presence of the Strongylus vulgaris was detected. It is important to highlight that the observation of this large strongyle was associated to the presence of cyathostomins (co-infection) and represented only 5\% of the larvae total retrieved in the coprocultures of these properties. The prevalence of the helminths mentioned in the equines analyzed, as well as of the Parascaris equorum, Oxyuris equi and Strongyloides westeri, are shown in Table 1.

Table 1. Prevalence of helminths in equines from the southern region of Rio Grande do Sul: prevalence in the properties and in the equines from 2016 to 2017

\begin{tabular}{lccc}
\hline Nematodes & Prevalence in the properties & Prevalence in equines & Average of EPG \\
\hline Cyathostominae & $100 \%$ & $96.36 \%$ & 1115.71 \\
Parascaris equorum & $75 \%$ & $12.21 \%$ & 42.34 \\
Oxyuris equi & $50 \%$ & $10.13 \%$ & N/A \\
Strongylus vulgaris & $16.67 \%$ & N/A & N/A \\
Strongyloides westeri & $8.33 \%$ & $3.12 \%$ & 5.84 \\
\hline
\end{tabular}

\section{Discussion}

The equines that took part in the study had been dewormed at least two months before. Considering the cyathostomins reproductive cycles, it is possible to see the infection becoming patent in two months. However, the large strongyles, ascarids, oxyurids and Strongyloides have prepatent periods greater than two months, which could have reduced the detection of these nematodes in some farms. It is highlighted that, in the great majority of the analyzed properties, the equines had been dewormed more than three months before. After the collection and quantitative analysis, it was possible to observe that $76.1 \%$ of the equines had presented egg counting above $500 \mathrm{EPG}$, which characterizes them as high egg shedders, indicating the necessity of anthelmintic treatment (Kaplan \& Nielsen, 2010).

The estimated prevalence of cyathostomins in the properties of the southern region of Rio Grande do Sul is high, coinciding with results found in other regions of Brazil and the world (Hinney et al., 2011; Kornás et al., 2010; Pereira \& Vianna, 2006). The cyathostomins generally represent $95-100 \%$ of the total parasitic 
load (Nielsen, 2012), and its high prevalence is related to the fast life cycles and the capacity of adaptation to new molecules and types of treatments (Kaplan \& Nielsen, 2010; Kornás et al., 2010). Through the EPG counting analysis, it is possible to identify the equines that expel a greater amount of helminths eggs and, thus, to detect which animals represent greater risk of pasture contamination, being these the targets of the selective control programs (Nielsen, 2015; Schneider et al., 2014).

In the present study, only two properties were positive for $S$. vulgaris. It is believed that the low prevalence of large strongyles in the region is related to its long prepatent period and the frequent use of antiparasitics. In the majority of the evaluated properties, the equines had been treated every two to three months with broad-spectrum anthelmintics (especially the ivermectin), acting on the large strongyles. These results are similar to the ones found in the literature (Barbosa et al., 2001; Hinney et al., 2011; Kornás et al., 2010) and agree with the fact that, although highly pathogenic, it is believed that the large strongyles have lost their epidemiologic importance (Love et al., 1999).

The prevalence of the $P$. equorum was of $12.2 \%$, and this ascarid was present in $3 / 4$ of the evaluated properties. In similar studies conducted in Brazil, the prevalence varies from 0 to 5\% (Barbosa et al., 2001; Pereira \& Vianna, 2006). At France, Laugier et al. (2012) had observed a variation in the prevalence of the P. equorum between $6.9 \%$ and $76.2 \%$. The infection by this ascarid was important especially in young equines, of up to seven months of age, due to low immunity against the parasite. In the first months of life of the young equines, after the exposition to the infectants and adult forms, the infection is controlled by the host itself occurring a reduction of the parasitic load (Laugier et al., 2012). These facts can justify the variation of results found in the literature.

Regarding the $O$. equi, a high occurrence in studies carried out in Brazil was reported. In the state of São Paulo, Pereira \& Vianna (2006) found a prevalence of 90.0\%, and Barbosa et al. (2001) had observed the presence of $O$. equi in $85.7 \%$ of the young animals and in $71.4 \%$ of the adults; both studies assessed parasites acquired through necropsy. By means of coprological examinations, Hinney et al. (2011) and Lem et al. (2012) found prevalence of $8.7 \%$ and $16.9 \%$, respectively, results that are similar to the present study. Infections by $O$. equi cause anal pruritus and can cause hirsute hairs and alopecia in the base of the tail, as the equines rub it against solid objects (Reinemeyer \& Nielsen, 2013). In one property, four animals presented injuries compatible with oxyuriasis and were positive in the coprological examination of McMaster. It is worth mentioning that, in the present study, the Graham method was not performed. This is a method of election for the diagnosis of $O$. equi and, consequently, the prevalence of this nematode could have been underestimated. Despite this, the McMaster technique can be used as an auxiliary diagnostic method. Hygiene measures are fundamental for the control of this parasite, including the cleaning of the perianal region for the removal of egg masses (Hinney et al., 2011).

The low frequency of $S$. westeri $(3.1 \%)$ found in the equines of this work is relevant. Adult mares can serve as reservoirs of larvae, making the infection of its young equines possible to be transmitted through lactation, thus enabling the transmission of clinical strongyloidiasis in the first weeks of life of foals; the infection of these young equines is more serious, and it may lead to death (Lucena et al., 2012). In a study carried out in Poland by Kornás et al. (2010), the $S$. westeri was detected in $4.0 \%$ of the properties and had greater prevalence in young equines.

\section{Conclusion}

The infections caused by nematodes, especially by cyathostomins, are common in equines of the southern region of Rio Grande do Sul. Apparently, the large strongyles have little epidemiologic importance in this region and, for this reason; the selective treatment can be adopted in the majority of the properties. The coprological monitoring is essential so that correct measures of control of these parasites can be developed.

\section{References}

Barbosa, O. F., Rocha, U. F., Silva, G. S., Soares, V. E., Veronez, V. A., Oliveira, G. P. \& Costa, A. J. (2001). A survey on Cyathostominae nematodes (Strongylidea, Strongylidae) in pasture bred horses from São Paulo State, Brazil. Semina: Ciências Agrárias, 22(1):21-26. 
Gordon, H. M. \& Whitlock, H. V. (1939). A new technique for counting nematode eggs in sheep faeces. Journal of the Council for Scientific and Industrial Research, 12(1):50-52.

Hinney, B., Wirtherle, N. C., Kyule, M., Miethe, N., Zessin, K. H. \& Clausen, P. H. (2011). Prevalence of helminths in horses in the state of Brandenburg, Germany. Parasitology Research, 1081083-1091.

Kaplan, R. M., Klei, T. R., Lyons, E. T., Lester, G., Courtney, C. H., French, D. D. \& Zhao, Y. (2004). Prevalence of anthelmintic resistant cyathostomes on horse farms. Journal of the American Veterinary Medical Association, 225(6):903-910.

Kaplan, R. M. \& Nielsen, M. K. (2010). An evidence-based approach to equine parasite control: It ain't the 60s anymore. Equine Veterinary Education, 22(6):306-316.

Kornás, S., Cabaret, J., Skalska, M. \& Nowosad, B. (2010). Horse infection with intestinal helminths in relation to age, sex, access to grass and farm system. Veterinary Parasitology, 174285-291.

Laugier, C., Sevin, C., Ménard, S. \& Maillard, K. (2012). Prevalence of Parascaris equorum infection in foals on French stud farms and first report of ivermectin-resistant $P$. equorum populations in France. Veterinary Parasitology, 188185-189.

Lem, M. F., Vincent, K. P., Pone, J. W. \& Joseph, T. (2012). Prevalence and intensity of gastro-intestinal helminths in horses in the Sudano-Guinean climatic zone of Cameroon. Tropical Parasitology, 245-48.

Love, S., Murphy, D. \& Mellor, D. (1999). Pathogenicity of cyathostome infection. Veterinary Parasitology, 85(2-3):113-122.

Lucena, R. B., Fighera, R. A. \& Barros, C. S. L. (2012). Mortalidade em potros associada ao parasitismo por Strongyloides westeri. Pesquisa Veterinária Brasileira, 32(5):401-404.

Molento, M. B., Antunes, J., Bentes, R. N. \& Coles, G. C. (2008). Anthelmintic resistant nematodes in Brazilian horses. Veterinary Record, 162384-385.

Nielsen, M. K. (2012). Sustainable equine parasite control: perspectives and research needs. Veterinary Parasitology, 185(1):32-44.

Nielsen, M. K. (2015). Universal challenges for parasite control: a perspective from equine parasitology. Trends in Parasitology, 31(7):282-284.

Peregrine, A. S., McEwen, B., Bienzle, D., Koch, T. G. \& Weese, J. S. (2006). Larval cyathostominosis in horses in Ontario: an emerging disease? The Canadian Veterinary Journal, 47(1):80-82.

Pereira, J. R. \& Vianna, S. S. S. (2006). Gastrointestinal parasitic worms in equines in the Paraíba Valley, State of São Paulo, Brazil. Veterinary Parasitology, 140(3-4):289-295.

Pierezan, F., Rissi, D. R., Oliveira Filho, J. C., Lucena, R. B., Tochetto, C., Flores, M. M. \& Barros, C. S. L. (2009). Enterite granulomatosa associada a larvas de ciatostomíneos em eqüinos no Rio Grande do Sul. Pesquisa Veterinária Brasileira, 29(5):382-386.

Reinemeyer, C. R. \& Nielsen, M. K. (2013). Handbook of equine parasite control. Iowa, USA: WileyBlackwell.

Relf, V. E., Morgan, E. R., Hodgkinson, J. E. \& Matthews, J. B. (2013). Helminth excretion with regard to age, gender and management practices on UK Thoroughbred studs. Parasitology, 140641-652.

Schneider, S., Pfister, K., Becher, A. M. \& Scheuerle, M. C. (2014). Strongyle infections and parasitic control strategies in German horses—a risk assessment. BMC Veterinary Research, 10(262):1-9.

Taylor, M. A., Coop, R. L. \& Wall, R. L. (2017). Parasitologia Veterinária. Rio de Janeiro, Brasil: Guanabara Koogan.

von Samson-Himmelstjerna, G. (2012). Anthelmintic resistance in equine parasites-detection, potential clinical relevance and implications for control. Veterinary Parasitology, 185(1):2-8.

Recebido: 12 de agosto, 2019.

Aprovado: 31 de outubro, 2019.

Publicado: 6 de janeiro, 2020.

Licenciamento: Este artigo é publicado na modalidade Acesso Aberto sob a licença Creative Commons Atribuição 4.0 (CC-BY 4.0), a qual permite uso irrestrito, distribuição, reprodução em qualquer meio, desde que o autor e a fonte sejam devidamente creditados. 